\title{
Begonia wuzhishanensis (sect. Diploclinium, Begoniaceae), a new species from Hainan Island, China
}

\author{
Ching-l Peng ${ }^{1 *}$, Xiao-Hua Jin ${ }^{2}$, Shin-Ming Ku ${ }^{1}$, Yoshiko Kono ${ }^{1}$, Han-Yau Huang ${ }^{1,3}$ and Hsun-An Yang ${ }^{1 *}$
}

\begin{abstract}
Background: Hainan is the largest island of the Indo-Burma Biodiversity Hotspot and has the best preserved and most extensive tropical forests in China. A recent study on distribution of endangered species in China identifies southern Hainan as one of eight hotspots for plant conservation in the country. In continuation of our studies of Asian Begonia, we report the discovery of an attractive undescribed species, B. wuzhishanensis C.-I Peng, X.H. Jin \& S.M. Ku, from Hainan Island.

Results: Living plant of the new species, Begonia wuzhishanensis, was collected in 2009 and cultivated in the experimental greenhouse for morphological and cytological studies. It flowered consecutively in 2012 and 2013 in the experimental greenhouse, Academia Sinica. It was assigned to the large, heterogeneous sect. Diploclinium. The chromosome number of this new species was determined to be $2 n=26$.

Conclusions: A careful study of literature, herbarium specimens and living plants, both in the wild and in cultivation, support the recognition of the new species Begonia wuzhishanensis, which is described in this paper. Begonia wuzhishanensis is currently known only from Fanyang, Wuzhishan Mountain in the center of the island. A line drawing, color plate, and a distribution map are provided to aid in identification.
\end{abstract}

Keywords: Begonia wuzhishanensis; Begoniaceae; Chromosome number; Flora of China; Hainan; New species; Sect. Diploclinium; Septal placentation

\section{Background}

Hainan is the largest island of the Indo-Burma Biodiversity Hotspot and has the best preserved and most extensive tropical forests in China (Deng et al. 2008; Zang and Ding 2009). The island harbors the Hainan Island Monsoon Rain Forest Ecoregion, one of the 26 terrestrial habitats of China internationally recognized by the World Wildlife Fund for its global ecological importance (Francisco-Ortega et al. 2010). A recent study on distribution of endangered species in China identifies southern Hainan as one of eight hotspots for plant conservation in the country (Zhang and Ma 2008). In Hainan eight species of Begonia, four of which endemic (B. hainanensis Chun \& F. Chun, B. howii Merr. \& Chun, B. peltatifolia H.L. Li, and B. sublongipes

\footnotetext{
* Correspondence: bopeng@sinica.edu.tw; shin34tfg@gmail.com ${ }^{1}$ Herbarium (HAST), Biodiversity Research Center, Academia Sinica, Nangang, Taipei 115, Taiwan

Full list of author information is available at the end of the article
}

Y.M. Shui) to the island, were documented (Gu et al. 2007). In continuation of our studies of Asian Begonia (e.g., Chung et al., 2014; Hughes et al. 2011; Nakamura et al. 2013; Peng et al. 2012, 2013, 2014; Rubite et al.: Begonia chingipengii [sect. Baryandra, Begoniaceae], a new species from Luzon Island, Philippines, submitted), we report the discovery of an additional undescribed species, B. wuzhishanensis, endemic to the island.

\section{Methods}

\section{Chromosome preparations}

Somatic chromosomes of the new species, Begonia wuzhishanensis ( $K u$ E Jin 2093) were examined using root tips. The methods of pretreatment, fixation and staining for chromosome observations followed Peng et al. (2012). Classification of the chromosome complements based on centromere position at mitotic metaphase follows Levan et al. (1964). Voucher specimens have been deposited in 
Herbarium, Biodiversity Research Center, Academia Sinica, Taipei (HAST).

\section{Cryo scanning electron microscopy}

A fresh leaf of Begonia wuzhishanensis (Ku \& Jin 2093) was dissected and attached to a stub. The samples were frozen with liquid nitrogen slush, then transferred to a sample preparation chamber at $-160^{\circ} \mathrm{C}$ and etched for $15 \mathrm{~min}$ at $-85^{\circ} \mathrm{C}$. After etching, the temperature reached $-130^{\circ} \mathrm{C}$ for sample fracturing and coating. After coating, the samples were transferred to the SEM chamber and observed at $-160^{\circ} \mathrm{C}$ with a cryo scanning electron microscope (FEI Quanta 200 SEM/Quorum Cryo System PP2000TR FEI).

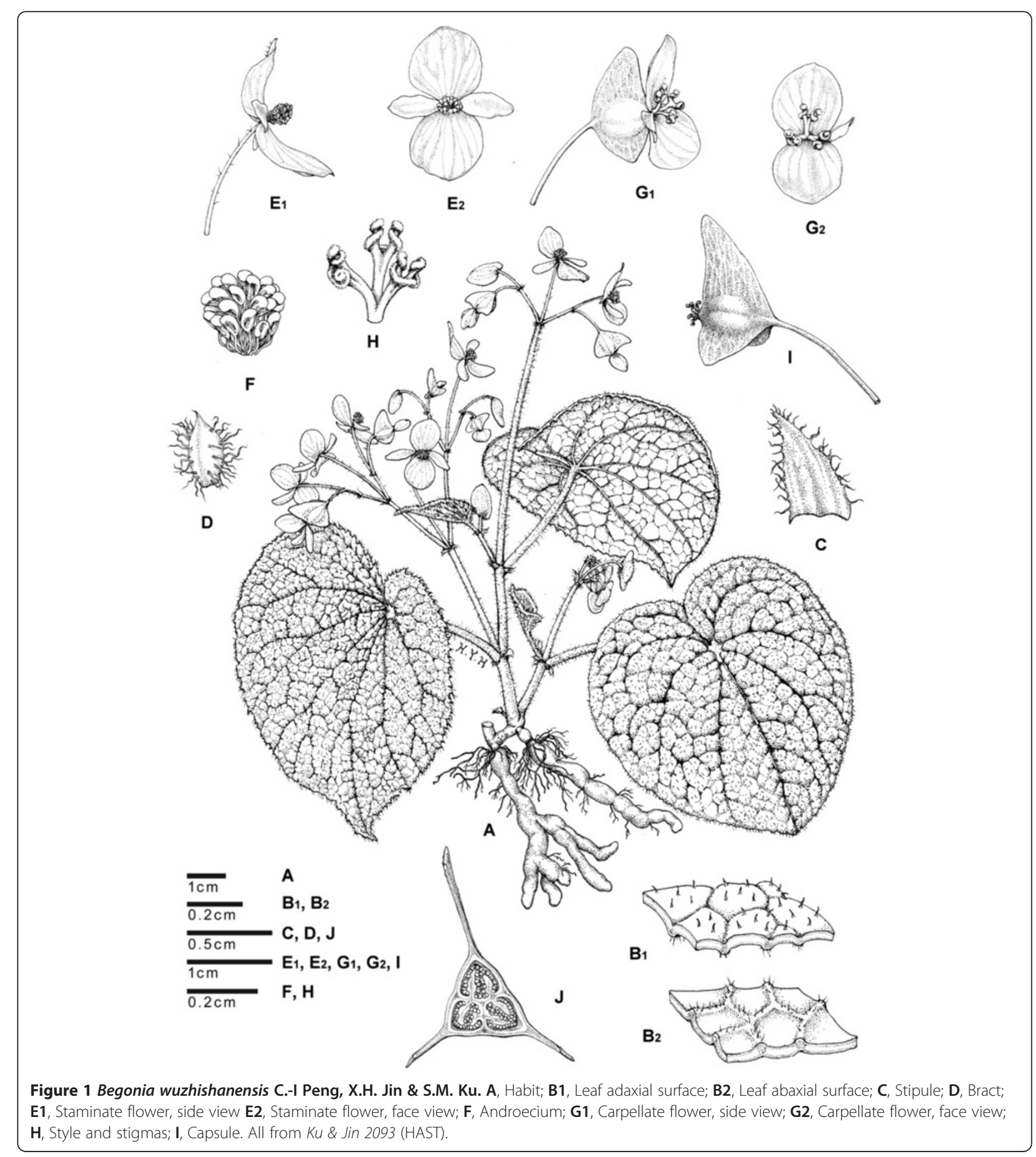




\section{Results and discussion}

Species description

Begonia wuzhishanensis C.-I Peng, X.H. Jin \& S.M. Ku, sp. nov. (sect. Diploclinium) -TYPE: CHINA, Hainan Province, Wuzhishan City, Fanyang Township, Nanyi
Village, on wet, mossy rocky slope by a stream in forest, elev. ca. 180 m, 18 $52^{\prime} 53^{\prime \prime} \mathrm{N}, 109^{\circ} 20^{\prime} 33^{\prime \prime E}, 10$ October 2009. Type specimens pressed from plants brought back from the field and cultivated in the experimental greenhouse, Academia Sinica, Taiwan, 3 December 2013. Shin-Ming
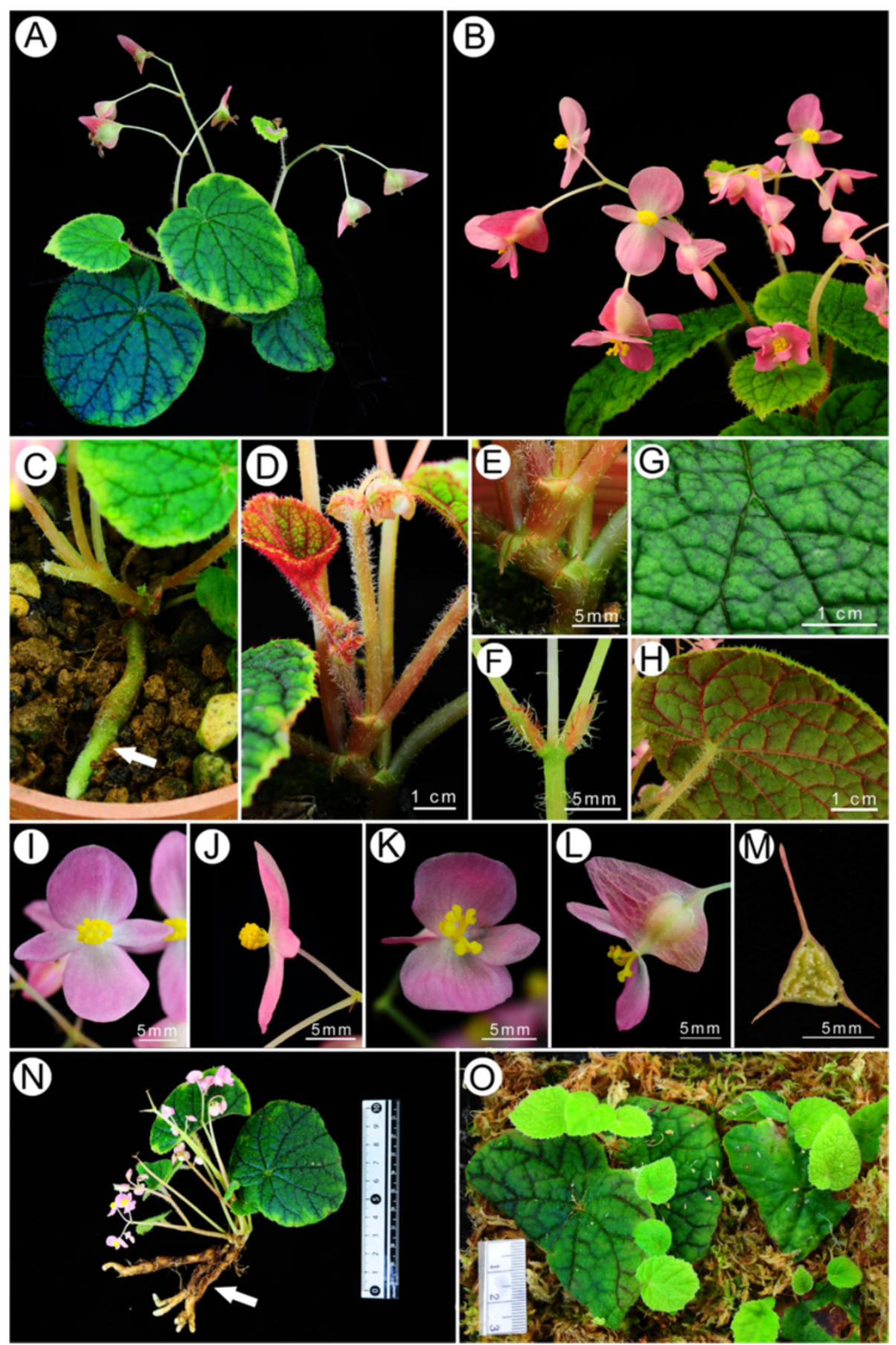

Figure 2 Begonia wuzhishanensis C.-I Peng, X.H. Jin \& S.M. Ku. A, Habit, leaf showing iridescence; B, Inflorescence; C, Elongate tuber (arrow); D, Erect stem; E, Stipules; $\mathbf{F}$, Bracts; G, Leaf adaxial surface; H, Leaf abaxial surface; I, Male flower, face view; J, Male flower, side view; K, Female flower, face view; L, Female flower, side view; $\mathbf{M}$, Cross-section of ovary; N, Plant with subterranean, branched, elongate tubers (arrow); O, Vegetative propagation. All from Ku \& Jin 2093 (HAST). 
Page 4 of 7

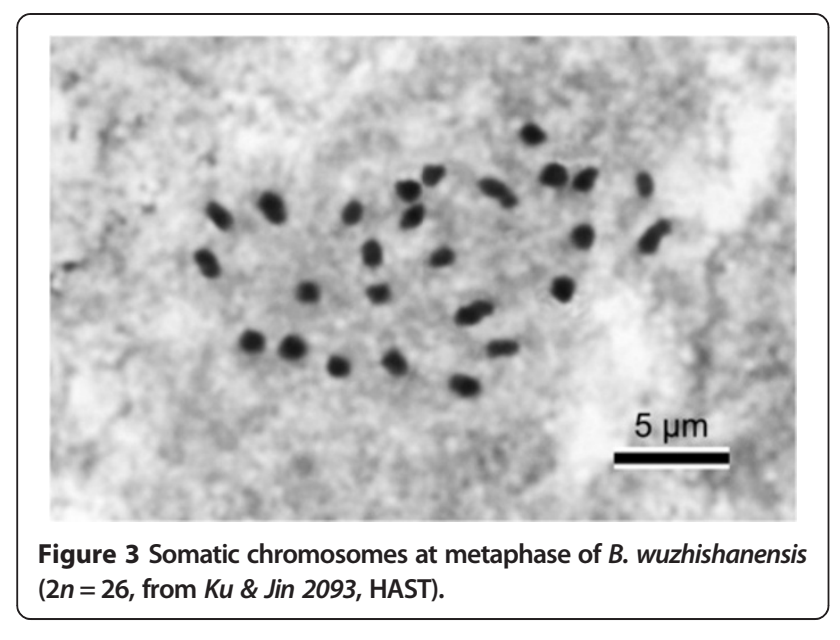

Ku $\mathcal{E}$ Xiao-Hua Jin 2093 (holotype: HAST; isotype: PE). 五指山秋海棠 Figures 1 and 2.

Herbs, monoecious, deciduous perennial, with elongate tubers. Tubers prostrate on soil surface or underground, to $7 \mathrm{~cm}$ long, $0.9 \mathrm{~cm}$ across, branched or unbranched. Stems erect, succulent, 0.3-0.5 cm across, to $20(-25) \mathrm{cm}$ high at anthesis, branched from lower nodes. Leaves alternate, petioles $2.5-4 \mathrm{~cm}$ long, $0.4 \mathrm{~cm}$ across; stipules triangular, margin fimbriate; leaf blade nearly symmetric, cordate, $3.5-8 \mathrm{~cm}$ long, 3-7.5 cm wide, chartaceous, adaxial surface green, slightly bullate, hirtellous, venation dark green and impressed, iridescent; leaf abaxial surface pale, veins reddish or red, manifestly elevated and hirtellous, margin irregularly double-serrate. Inflorescences axillary, dichasial cymes branched 2-3 times, peduncle $10-18 \mathrm{~cm}$ long, ca. $0.3 \mathrm{~cm}$ in diameter, hirtellous; lower bracts ovate, ca. $0.5 \mathrm{~cm}$ long, $0.3 \mathrm{~cm}$ wide, margin fimbriate, abaxially densely hirtellous, eventually deciduous. Staminate flower: pedicel sparingly hirtellous to nearly glabrous, 2-4 cm long, tepals 4, pinkish, outer 2 broadly ovate, ca. $1 \mathrm{~cm}$ long, $0.8 \mathrm{~cm}$ wide, abaxially glabrous to hirtellous, inner 2 lanceolate, ca. $0.8 \mathrm{~cm}$ long, $0.4 \mathrm{~cm}$ wide, glabrous; androecium zygomorphic, ca. $0.3 \mathrm{~cm}$ across; stamens ca. 25-30; filaments free, 0.1-0.2 cm long; anthers 2-locular, obovoid. Carpellate flower: pedicel sparingly hirtellous to subglabrous, 1.3-1.6 cm long, tepals 3 , outer 2 broadly ovate to suborbicular, ca. $0.8 \mathrm{~cm}$ long, $0.8 \mathrm{~cm}$ wide, inner 1 lanceolate, ca. $0.6 \mathrm{~cm}$ long, $0.4 \mathrm{~cm}$ wide; ovary trigonous-ellipsoid, ca. $0.7 \mathrm{~cm}$ long, $0.5 \mathrm{~cm}$ across, white, glabrous, 3-winged, 3-locular; placentas septal; styles 3. Capsule nodding, ca. $1.6 \mathrm{~cm}$ long, $1.2 \mathrm{~cm}$ wide, wings unequal, triangular, abaxial wing ca. $1.2 \mathrm{~cm}$ tall, lateral wings ca. $0.4 \mathrm{~cm}$ tall, styles persistent.

\section{Additional specimens examined}

CHINA. Hainan Province, Wuzhishan City, Fanyang, in forest, elev. ca. 200-500 m, 15 October 2003, Xiao-Hua Jin 5208; ca. 300-500 m, 20 October 2003, Xiao-Hua Jin $5284(\mathrm{PE})$.
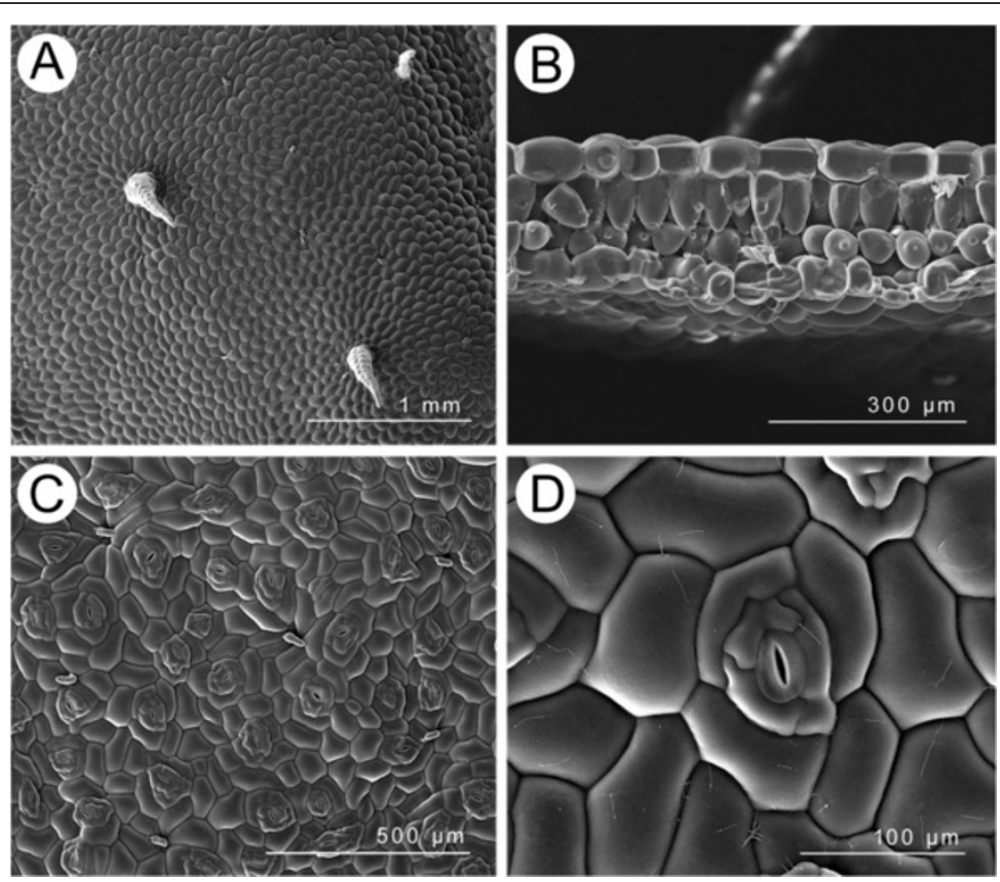

Figure 4 Leaf SEM microphotographs of $\boldsymbol{B}$. wuzhishanensis. A, Adaxial surfaces; B, Cross section; C, Abaxial surfaces; D, Stomata complex. 


\section{Chromosome cytology}

Somatic chromosomes at metaphase of $B$. wuzhishanensis (Ku \& Jin 2093, HAST) were determined to be $2 n=26$ (Figure 3). The 26 chromosomes gradually varied from ca. 1.0 to $2.0 \mu \mathrm{m}$ long in length. A pair of the longest chromosomes has centromeres at submedian; several chromosomes at median, however, those of smaller chromosomes could not be determined. Satellites were not observed.

Begonia wuzhishanensis belongs to the heterogeneous section Diploclinium, which comprises ca. 130 species (Doorenbos et al. 1998; Hughes and Pullan 2007). To our knowledge, 16 species of the section were cytologically studied. They exhibited a wide variation of chromosome numbers as $2 n=22,24,26,28,30,32,36,38,46,52,82$. Somatic chromosome number of $2 n=26$ was previously reported in two species: B. acaulis Merr. \& L.M. Perry (Papua New Guinea, Legro and Doorenbos 1969) and $B$. grandis Dryand. (China and Japan, Nakata et al. 2012).

\section{Leaf anatomy and vestiture}

Adaxial surface with scarce multiseriate trichomes (Figure 4A); cross section ca. $220 \mu \mathrm{m}$ thick, epidermis single-layered on both surfaces, hypodermis absent, palisade tissue and spongy tissue both single-layered (Figure 4B); abaxial surface with multiseriate trichomes on nerves, stomata complex single, helicocytic, nearly flat (Figure 4C,D).

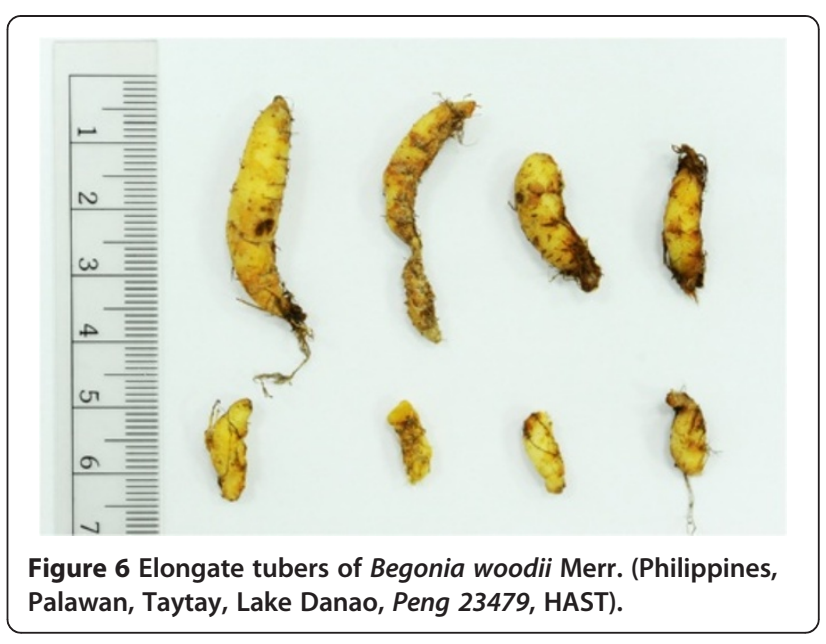

\section{Ecology and distribution}

Wuzhishan $(1,876 \mathrm{~m})$, located in the center of Hainan, is the highest mountain on the island. Begonia wuzhishanensis is a rare species found at lower part (ca. 200-500 m altitude) of Wuzhishan (Figure 5). It occurs on wet mossy rocks by streams in tropical forest.

\section{Etymology}

The specific epithet is derived from the type locality, Wuzhishan ('Five-fingered Mountain', literally) of Hainan Island, China.

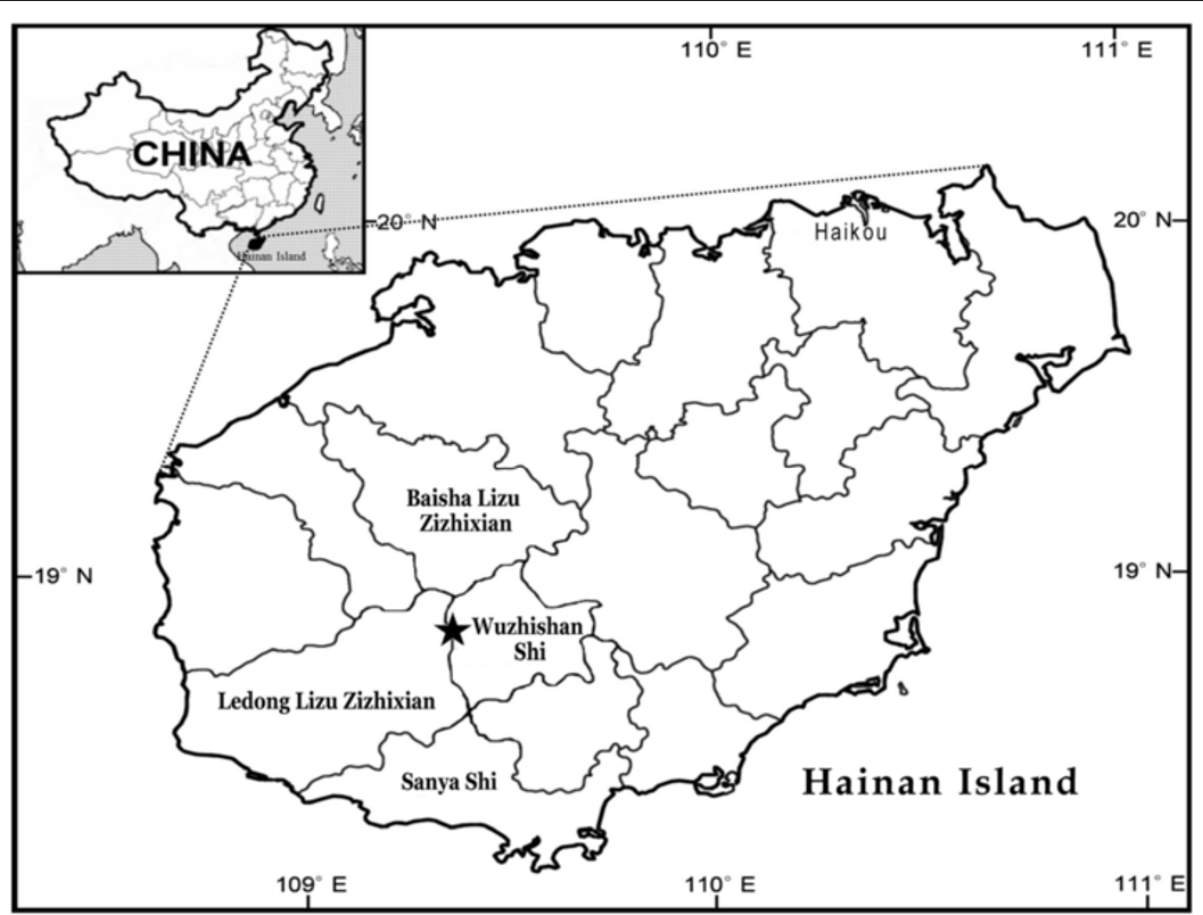

Figure 5 Distribution of Begonia wuzhishanensis $(\star)$ in Hainan Island. 

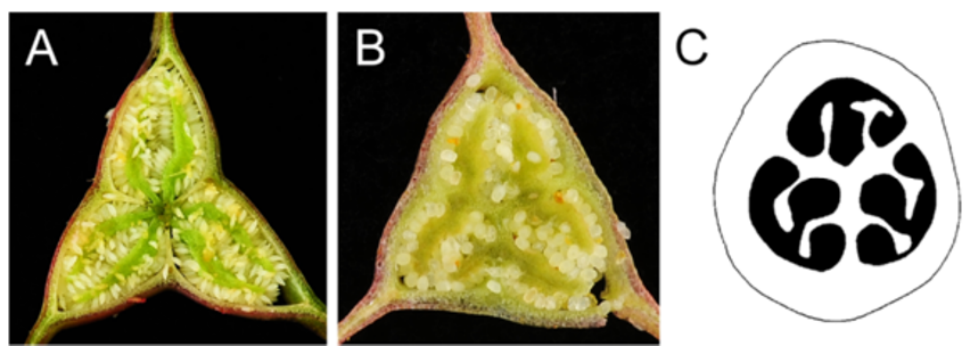

Figure 7 Placentations. A. Typical axile placentation (Begonia ravenii C.I Peng \& Y.K. Chen, sect. Diploclinium); B. Septal placentation (B. wuzhishanensis); C. Schematic drawing of septal placentation (adopted from Reitsma, 1984: Figure 1D).

\section{Phenology}

Flowering from August to December; fruiting from October to December.

\section{Cultivation}

Begonia wuzhishanensis can be grown from seeds. Alternatively, they can be propagated by the elongate tubers or leaf cuttings with ease (Figure 2O).

\section{Notes}

Begonia wuzhishanensis has prominent elongate tubers that are rarely encountered in the genus. This feature resembles those observed in B. lithophila C.Y. Wu (sect. Reichenheimia; Li 2006) from Yunnan, China and B. woodii Merr. (sect. Baryandra) from Palawan, the Philippines (Figure 6). The perennating tubers of $B$. woodii have been erroneously interpreted as short rhizomes in the past (Merrill 1925; Hughes et al. 2010).

Placentation of $B$. wuzhishanensis is noteworthy: its ovary is 3-locular with 2 placentas each growing from middle of the septa (Figures 1J, 2M, 7B). Such placentation was classified as 'septal' in African Begonia (Figure 7C; Reitsma 1984). Septal placentation was also observed in part of the ovary of some species in the Asian sect. Coelocentrum (e.g. B. aurantiflora C.-I Peng, Yan Liu \& S.M. Ku, Peng et al. 2008: Figure one; B. bamaensis Yan Liu \& C.-I Peng, Liu et al. 2007: Figure one; B. ×breviscapa C.-I Peng, Yan Liu \& S.M. Ku, Peng et al. 2010: Figure one; B. debaoensis C.-I Peng, Yan Liu \& S.M. Ku, Ku et al. 2006: Figure one; $B$. semiparietalis Yan Liu, S.M. Ku \& C.-I Peng, $\mathrm{Ku}$ et al.

Table 1 Comparison of Begonia wuzhishanensis, B. fimbristipula and B. obsolescens

\begin{tabular}{llll}
\hline & B. wuzhishanensis & B. fimbristipula & B. obsolescens \\
\hline Perennating by & Elongate tubers & $\begin{array}{l}\text { Subglobose } \\
\text { Tubers }\end{array}$ & Rhizomes \\
Leaf shape & Nearly symmetric & $\begin{array}{l}\text { Nearly } \\
\text { symmetric }\end{array}$ & Asymmetric \\
$\begin{array}{l}\text { Tepal number in } \\
\text { carpellate flower }\end{array}$ & 3 & 5 \\
Placentation & Septal & Axile & Axile \\
\hline
\end{tabular}

2006: Figure nine). With 3-locular ovaries, bifid placentas and perennating tubers, etc. but without axile placentation in B. wuzhishanenis (Figure 7B), we have tentatively placed it in the polymorphic and 'dust-bin' sect. Diploclinium (Rubite et al. 2013). Further molecular phylogenetic studies to clarify its placement are underway.

Begonia wuzhishanensis somewhat resembles B. obsolescens Irmsch. and B. fimbristipula Hance. Comparison of salient features of the three species is provided in Table 1.

\section{Conclusions}

A careful study of literature, herbarium specimens and living plants, both in the wild and in cultivation, support the recognition of the new species Begonia wuzhishanensis. It is currently known only from Fanyang, Wuzhishan Mountain in the center of Hainan island, China. Begonia wuzhishanensis is unique in having elongate tubers and septal placentation. It is tentatively assigned to sect. Diploclinium. Further studies to clarify its phylogenetic position are underway.

\section{Competing interests}

The authors declare that they have no competing interests.

\section{Authors' contributions}

CIP discovered the new species from PE herbarium, brought living materials into cultivation, and prepared the final version of the manuscript; SMK, guided by $\mathrm{XHJ}$, collected living plants from the field and prepared the distribution map; HAY carried out morphological studies, prepared the color plate, and drafted earlier versions of the manuscript; YK carried out the cytological study; $\mathrm{HYH}$ assisted with morphological studies and prepared the line drawing; XHJ collected the new species in 2003 and 2009, and provided field data. All authors read and approved the final manuscript.

\section{Acknowledgements}

We thank Ms. Victoria McMichael, serials librarian of the Missouri Botanical Garden for providing useful references. This study was supported in part by grants from National Science Council and Academia Sinica, Taiwan to Ching-I Peng (HAST).

\footnotetext{
Author details

${ }^{1}$ Herbarium (HAST), Biodiversity Research Center, Academia Sinica, Nangang Taipei 115, Taiwan. ${ }^{2}$ State Key Laboratory of Systematic and Evolutionary Botany \& Herbarium, Institute of Botany, Chinese Academy of Sciences, Beijing 100093, China. ${ }^{3}$ School of Forestry and Resource Conservation, National Taiwan University, Daan, Taipei 106, Taiwan.
}

Received: 18 December 2013 Accepted: 27 December 2013 Published: 5 February 2014 


\section{References}

Chung K-F, Leong W-C, Rubite RR, Repin R, Liu Y, Peng C-I (2014) Phylogenetic analyses of Begonia sect. Coelocentrum and allied limestone species of China shed light on the evolution of Sino-Vietnamese karst flora. Bot Stud: 55:1 doi:10.1186/1999-3110-55-1

Deng F, Zang R, Chen B (2008) Identification of functional groups in an old-growth tropical montane rain forest on Hainan Island, China. Forest Ecol Manag 255:1820-1830

Doorenbos J, Sosef MSM, de Wilde JJFE (1998) The sections of Begonia including descriptions keys and species lists. Studies in Begoniaceae VI. Wageningen Agricultural University, The Netherlands

Francisco-Ortega J, Wang Z-S, Wang F-G, Xing F-W, Liu H, Xu H, Xu W-X, Luo Y-B, Song S-Q, Gale S, Boufford DE, Maunder M, An S-Q (2010) Seed plant endemism on Hainan Island: a framework for conservation actions. Bot Rev 76:346-376

Gu C, Peng C-I, Turland NJ (2007) Begoniaceae. In: Wu Z-Y, Raven PH, Hong D-Y (ed) Flora of China, vol 13. Science Press, Beijing \& Missouri Botanical Garden Press, St. Louis, pp 153-207

Hughes M, Coyle C, Rubite RR (2010) A revision of Begonia section Diploclinium (Begoniaceae) on the Philippine Island of Palawan, including five new species. Edinburgh J Bot 67(1):123-140

Hughes M, Pullan M (2007) Southeast Asian Begonia Database. Electronic publication accessible via www.rbge.org.uk. Accessed 7 Feb 2014

Hughes M, Rubite RR, Kono Y, Peng C-I (2011) Begonia blancii (sect. Diploclinium, Begoniaceae), a new species endemic to the Philippine island of Palawan. Bot Stud 52:203-209

Ku S-M, Liu Y, Peng C-I (2006) Four new species of Begonia sect. Coelocentrum (Begoniaceae) from limestone areas in Guangxi, China. Bot Stud 47:207-222

Legro RAH, Doorenbos J (1969) Chromosome numbers in Begonia 1. Netherlands J Agric Sci 17:189-202

Levan A, Fredga K, Sandberg AA (1964) Nomenclature for centromeric position on chromosomes. Hereditas 52:201-220

Li H-Z (2006) Studies on conservation biology of Begonia sect. Reichenheimia in China. Ph. D. dissertation. Kunming Institute of Botany, Chinese Academy of Sciences, Kunming

Liu Y, Ku S-M, Peng C-I (2007) Begonia bamaensis (sect. Coelocentrum, Begoniaceae), a new species from limestone areas in Guangxi, China. Bot Stud 48:465-473

Merrill ED (1925) Additions to our knowledge of the Philippine flora I. Philipp. J. Sci. 26(4):477-483

Nakamura K, Rubite RR, Kono Y, Callado JR, Peng C-I (2013) Begonia tandangil (Begoniaceae, section Baryandra), a new species from Luzon Island, the Philippines. Phytotaxa 145(1):27-37. http://dx.doi.org/10.11646/phytotaxa.145.1.3

Nakata M, Ueno T, Li J-X, Li H-Z, Wang Z-L, Lu Y-X, Shen Y-G, Guan K-Y (2012) Chromosome number and pollen fertility of Begonia grandis (Begoniaceae) from Japan and China. Bull Bot Gard Toyama 17:23-29

Peng C-I, Liu Y, Ku S-M (2008) Begonia aurantiflora (sect. Coelocentrum, Begoniaceae), a new species from limestone areas in Guangxi, China. Bot Stud 49:83-92

Peng C-I, Liu Y, Ku S-M, Kono Y, Chung K-F (2010) Begonia x breviscapa (Begoniaceae), a new intersectional natural hybrid from limestone areas in Guangxi, China. Bot Stud 51:107-117

Peng C-I, Ku S-M, Kono Y, Liu Y (2012) Begonia chongzuoensis (sect. Coelocentrum, Begoniaceae), a new calciphile from Guangxi, China. Bot Stud 53:283-290

Peng C-I, Yang H-A, Kono Y, Chung K-F, Huang Y-S, Wu W-H, Liu Y (2013) Novelties in Begonia sect. Coelocentrum: B. longgangensis and B. ferox from limestone areas in Guangxi, China. Bot Stud 54:44. doi:10.1186/1999-3110-54-44

Peng C-I, Wang H, Kono Y, Yang H-A (2014) Begonia wui-senioris (sect. Platycentrum, Begoniaceae), a new species from Myanmar. Bot Stud 55: (in press)

Reitsma JM (1984) Placentation in Begonias from the African continent. Meded. Landbouwhogeschool Wageningen 83-9:21-53

Rubite RR, Hughes M, Alejandro GJD, Peng C-I (2013) Recircumscription of Begonia sect. Baryandra (Begoniaceae): evidence from molecular data. Bot Stud 54:38. doi:10.1186/1999-3110-54-38

Zang R, Ding Y (2009) Forest recovery on abandoned logging roads in a tropical montane rain forest of Hainan Island, China. Acta Oecol 35:462-470

Zhang Y-B, Ma K-P (2008) Geographic distribution patterns and status assessment of threatened plants in China. Biodivers Conserv 17:1783-1798

doi:10.1186/1999-3110-55-24

Cite this article as: Peng et al:: Begonia wuzhishanensis (sect. Diploclinium, Begoniaceae), a new species from Hainan Island, China. Botanical Studies 2014 55:24.

\section{Submit your manuscript to a SpringerOpen ${ }^{\odot}$ journal and benefit from:}

- Convenient online submission

- Rigorous peer review

- Immediate publication on acceptance

- Open access: articles freely available online

- High visibility within the field

- Retaining the copyright to your article

Submit your next manuscript at $\gg$ springeropen.com 